\title{
内腸骨動脈結紮術の下部尿管におよぼす影響について
}

\author{
日本大学医学部泌尿器科教室 今 泉新
(主任 永田正夫教授)
}

\section{THE EFFECT OF LIGATION OF THE INTERNAL ILIAC ARTERIES UPON THE LOWER URETER}

\section{Arata Imaizumi}

The Department of Urology, Nihon University School of Medicine

(Director: Prof. Masao NAGATA)

Controversy continued as to whether ligation of the internal iliac arteries can result in ischaemic necrosis of the lower ureter. In order to elucidate this point of dispute,

1) The superior vesical arteries of the rabbit were ligated and its ureter was histologically studied from next day through the 350th day after the operation. As a result, no particular abnormalities were demonstrated in the ureteral wall in general except for slight vacuolization of the ureteral epithelial cells and thinning of the muscular layer, and ischaemic necrosis was found in none of the cases.

2) Twenty-eight cases of recurrence of papillary bladder tumor and three cases of re-operation after prostatectomy were subjected to ligation of the bilateral internal iliac arteries. The IVP, cystogram and indigocarmin test performed on these cases proved improvement of the pre-operation conditions in most of them. Part of this success may be attributed to the excision of the papillary bladder tumor concurrently conducted. In none of the cases developed urinary fistula.

From the facts cited above, it was speculated that, if the vessel network surrounding the lower ureter is not injured, supplementary circulation comes to be established and ischaemic necrosis does not take place.

\section{I 緒言}

内腸骨動脈結紮術は, 古くから知られている手術法で あるが，この手術を行らことにより内腸骨動脈支配領域 臓器の栄養障害の発生が一部の人により危ぶまれたが, 現在では殆んど影響のないものと考兄られている゙ .

しかし，この手術を行うことによつて尿管，殊に下部 尿管の ischaemic necrosis の発生の有無については,な お議論が分かれているところである。

私は, 協同研究者 ${ }^{2}$ とともに再発の多い膀脂癌の確実 な再発防止法として, 膀朕癌の剔出とともに両側内腸骨 動脈結禁術を行つているので, 本手術の尿管, 特に下部 尿管におよぼす影響について検討し，いささか知見を得 たので報告する。

\section{II 動物実験}

\section{A 実験動物}

動脈の分布が比較的人に類似しており，操作の容易な ことから体重 $2.5 \mathrm{~kg}$ 以上の雄性家鬼を用いた。

\section{B 実験方法}

家鬼を背位に固定し，腹部を剃毛，消毒後開腹し，家
鬼では上膀胱動脈が直接総腸骨動脈から分技し，これか ら出る尿管技が主として下部尿管を栄養しており, 他に も内腸骨動脈系の動脈分技が細かに下部尿管に分布して おるといらことから両側上膀胱動脈の結紮を実施した.

動脈結禁後，それぞれ1日，5日，10日，15日，20 日，25日，40日，50日，60日，90日，100日，360日後 に屠殺し, 膀脱壁から上方約 $2.5 \mathrm{~cm}$ での尿管を剔出, 正常家鬼の下部尿管とともに横断標本を作成, へマトキ シリンエオジン, エラスチカワンギーソン, アザンマロ リ一染色を施して, 組織学的に検索した.

それぞれの実験には，家鬼 $2 \sim 3$ 羽づつを使用した。

C 実験結果

1. 正常家鬼

下部尿管も他部の尿管と同様に内層, 中間層, 外層の 3 層よりなるが，尿管周囲組織の血管が他部のものより も比較的豊富である（図 1 ）.

イ）内層（図 2 ）: 粘膜層と粘膜下固有層よりなる. 粘膜層には数層の移行上皮があり, 固有層は dense な内 側と, 比較的 loose な外側の結合織とよりなり, 次の筋 
図 1

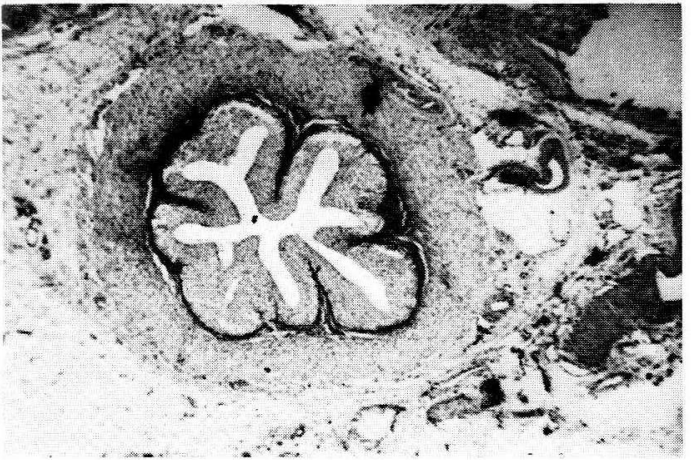

図 3

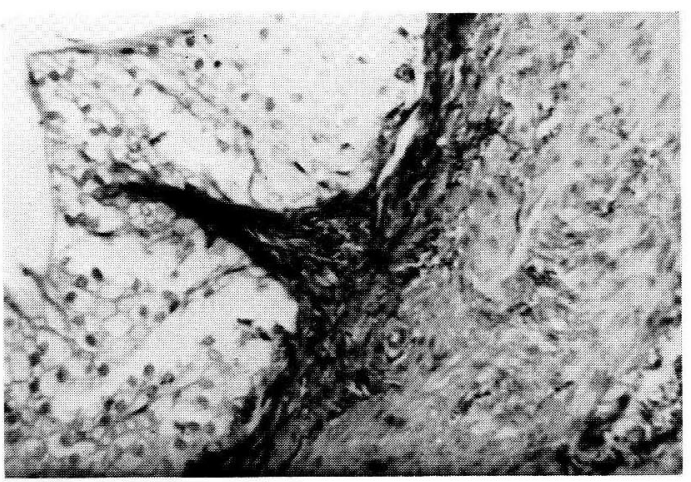

网 5

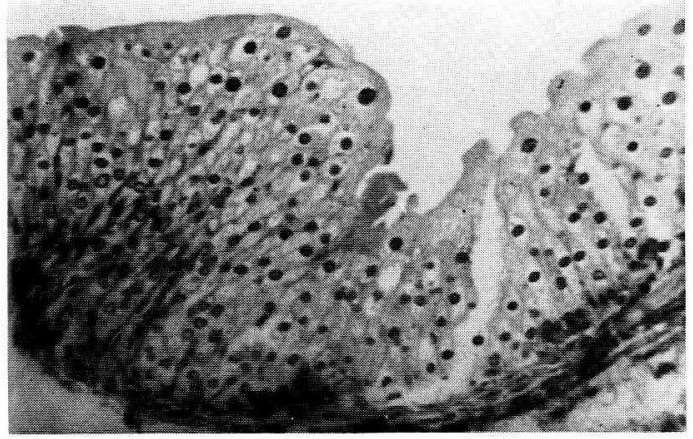

図 2

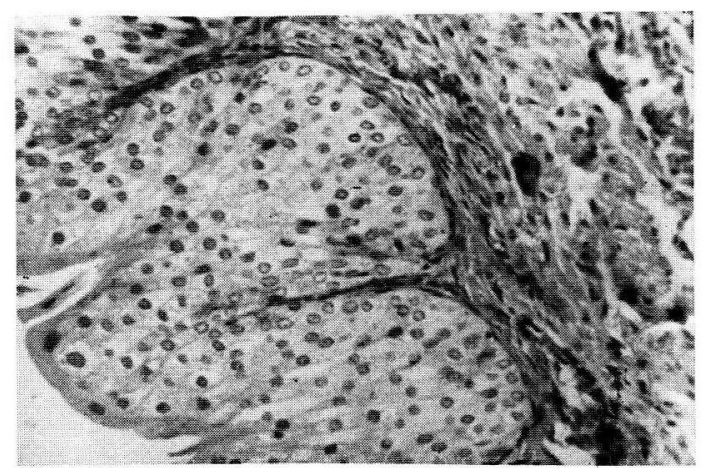

図 4
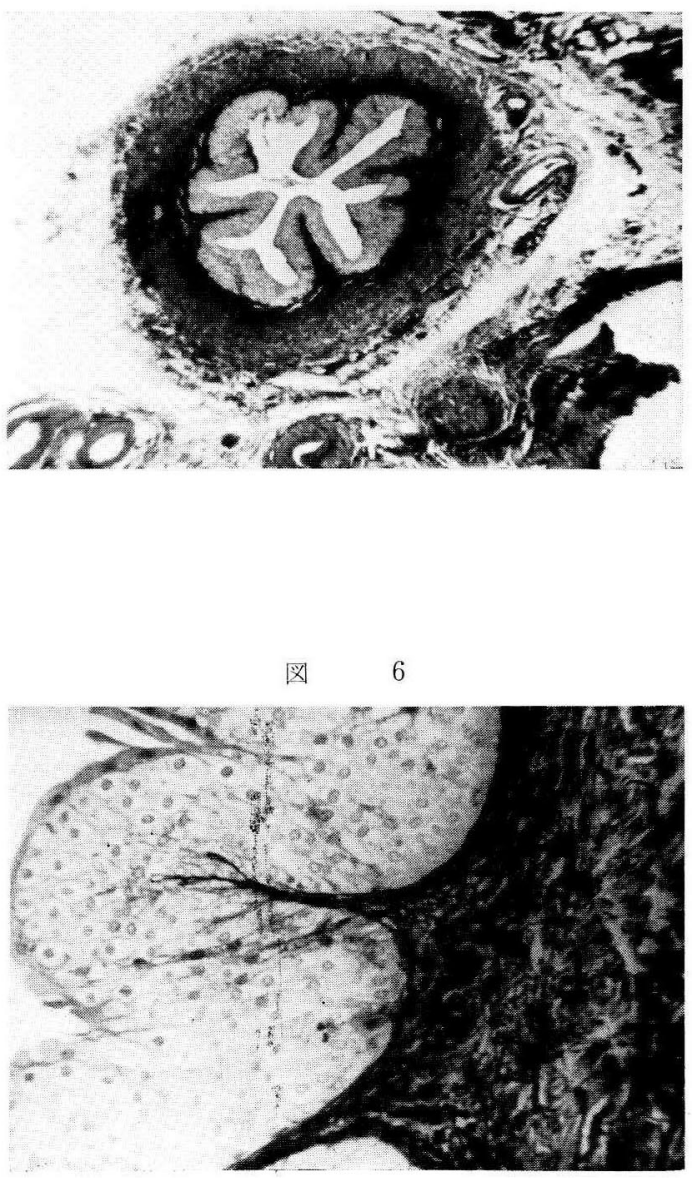
図 7
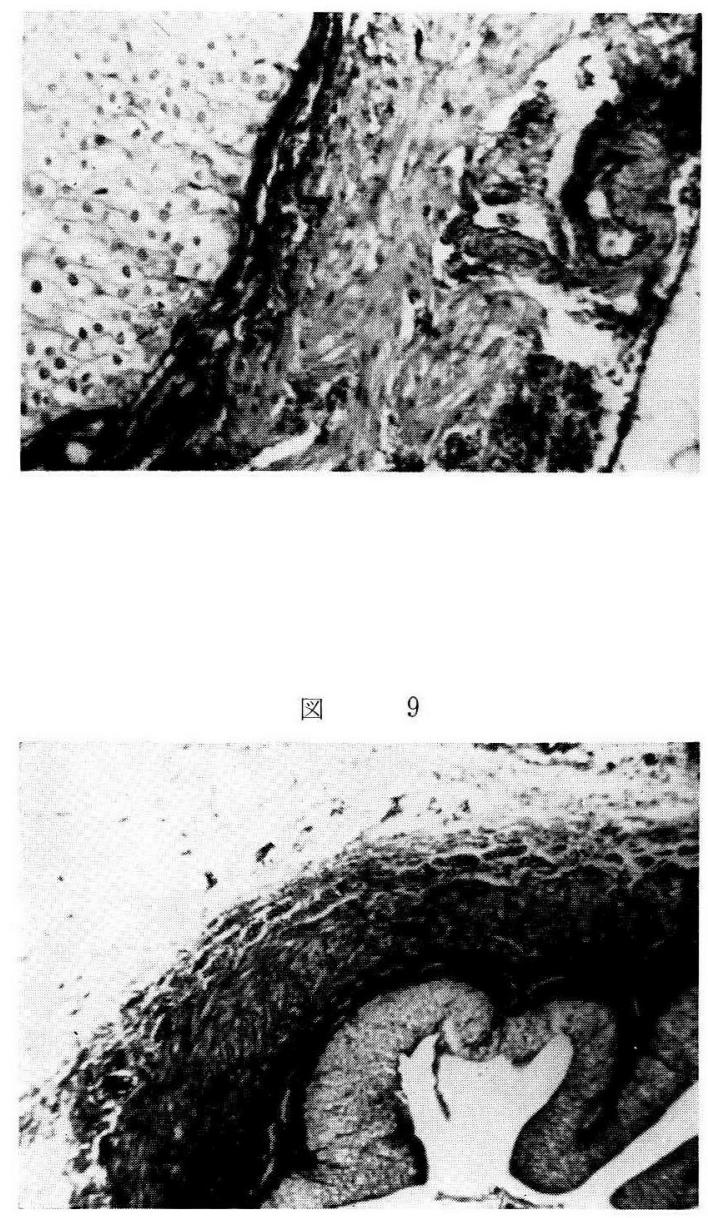

図 11

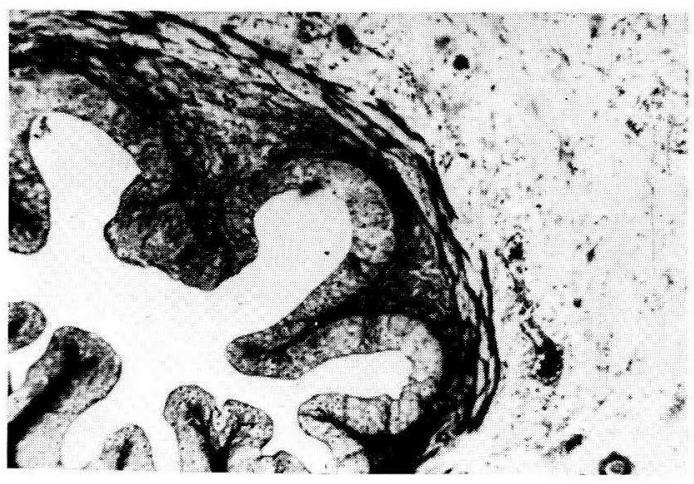

闵 8

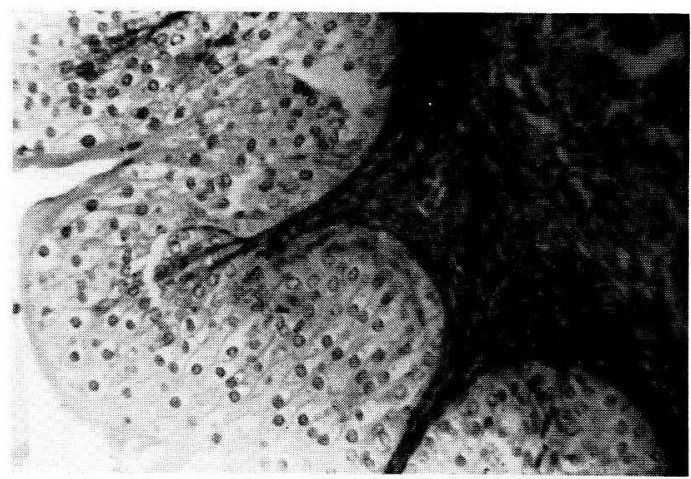

図 10

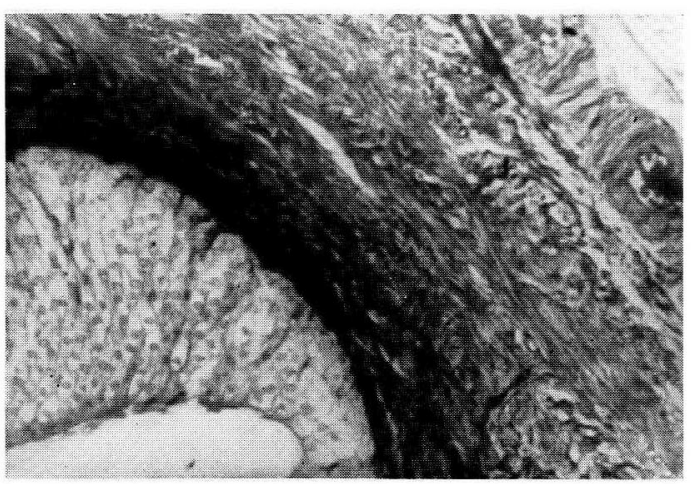

図 12

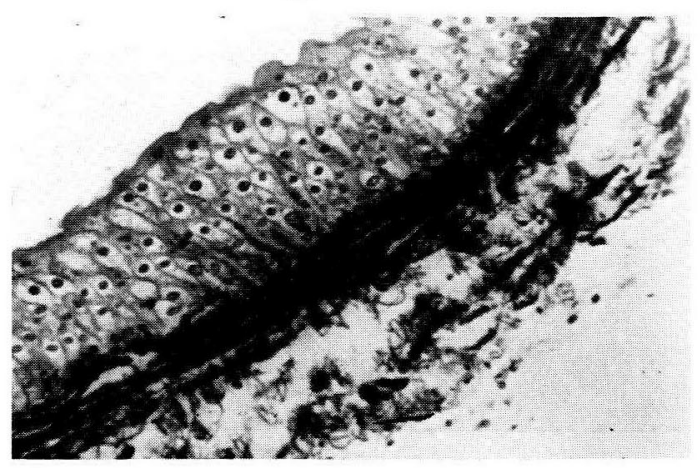


図

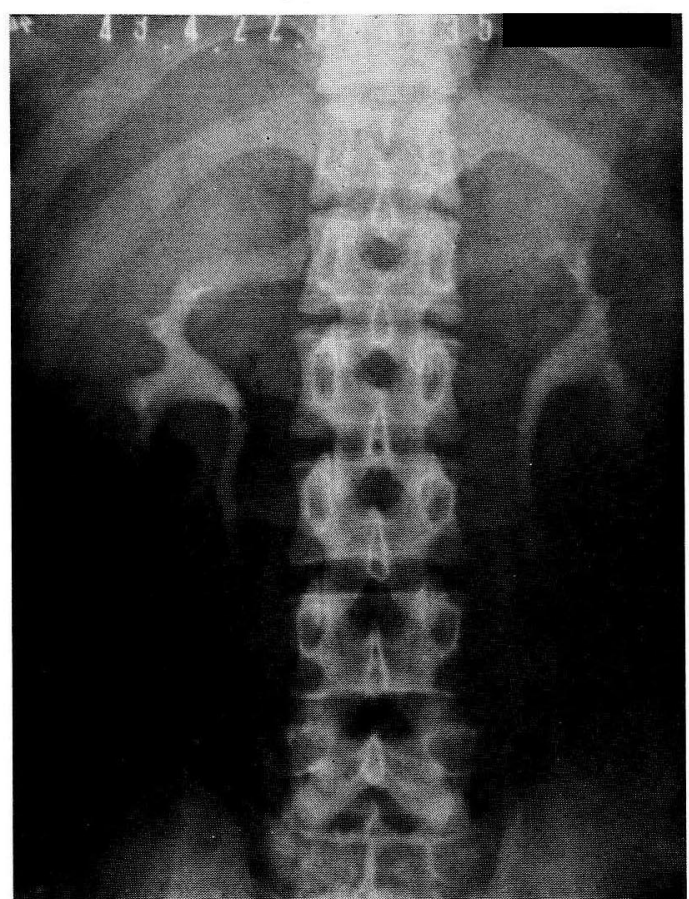

図 15

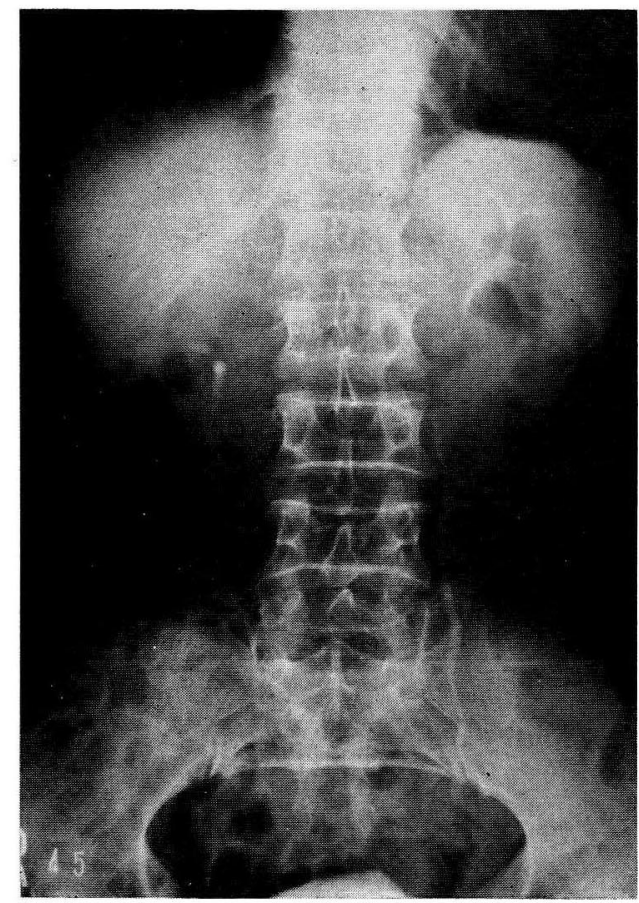

叉 14

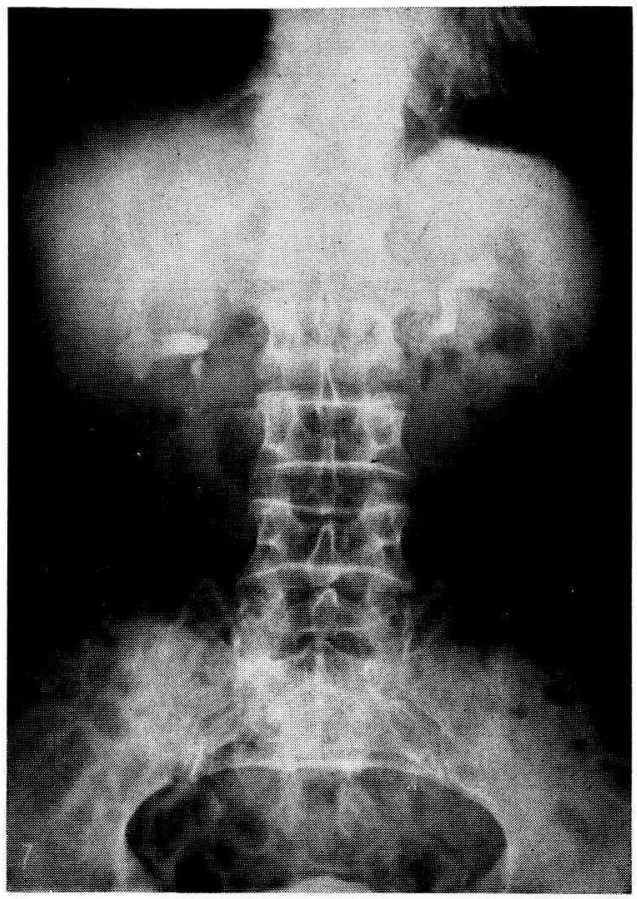

図 16

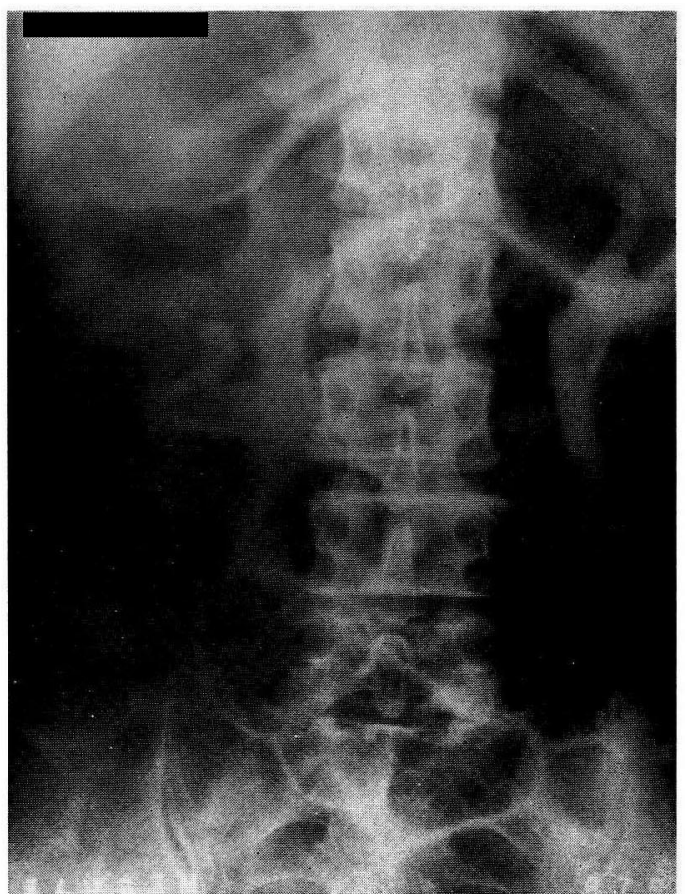


図 17

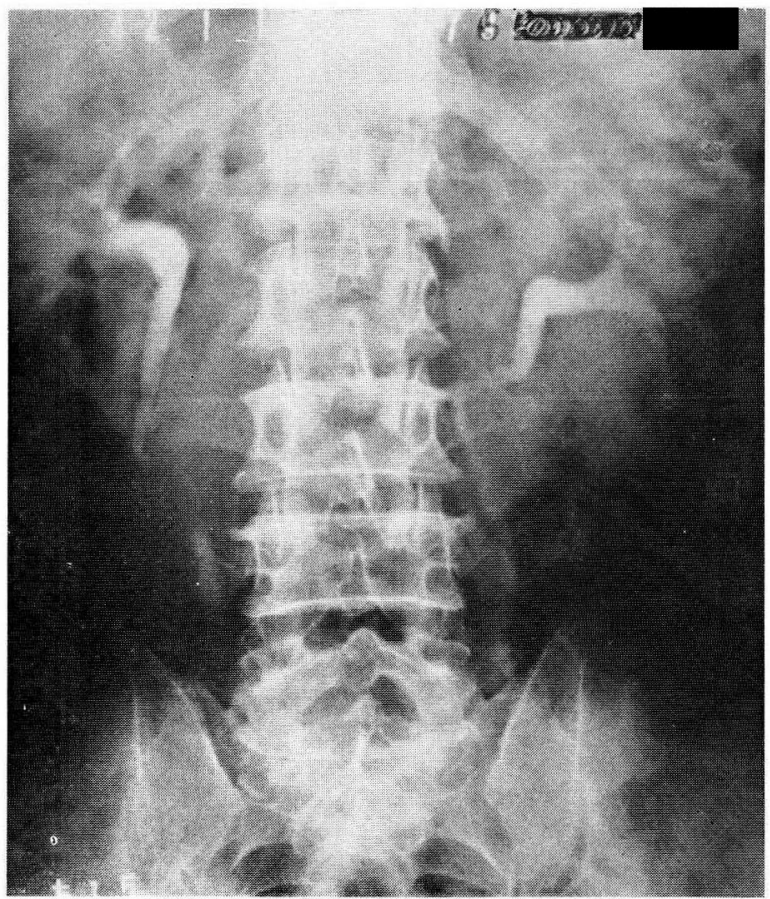

図 19

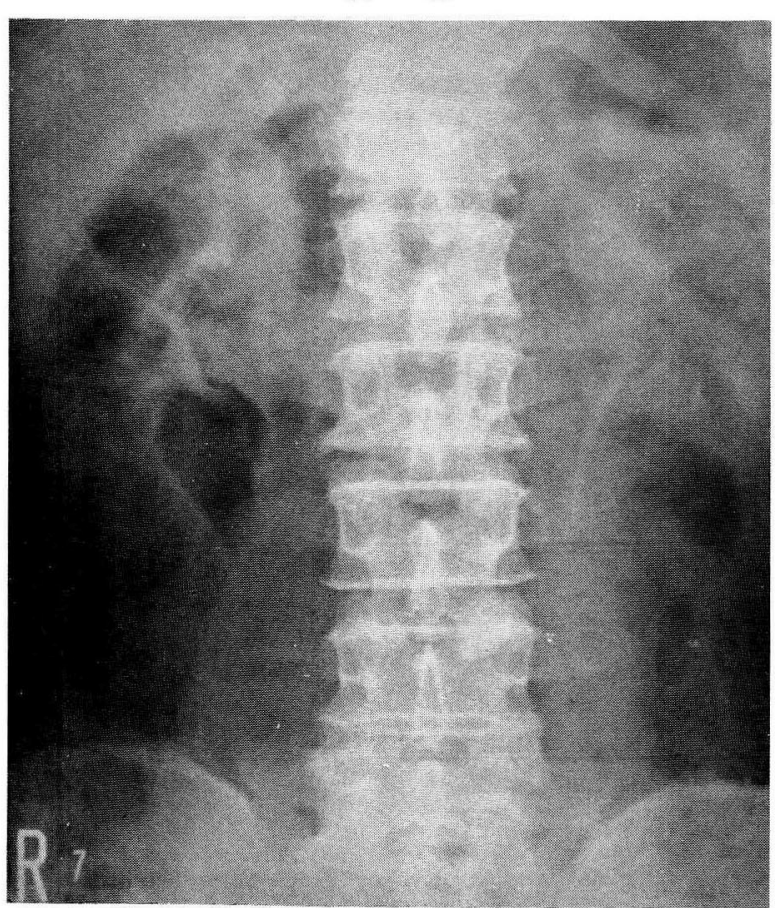

図

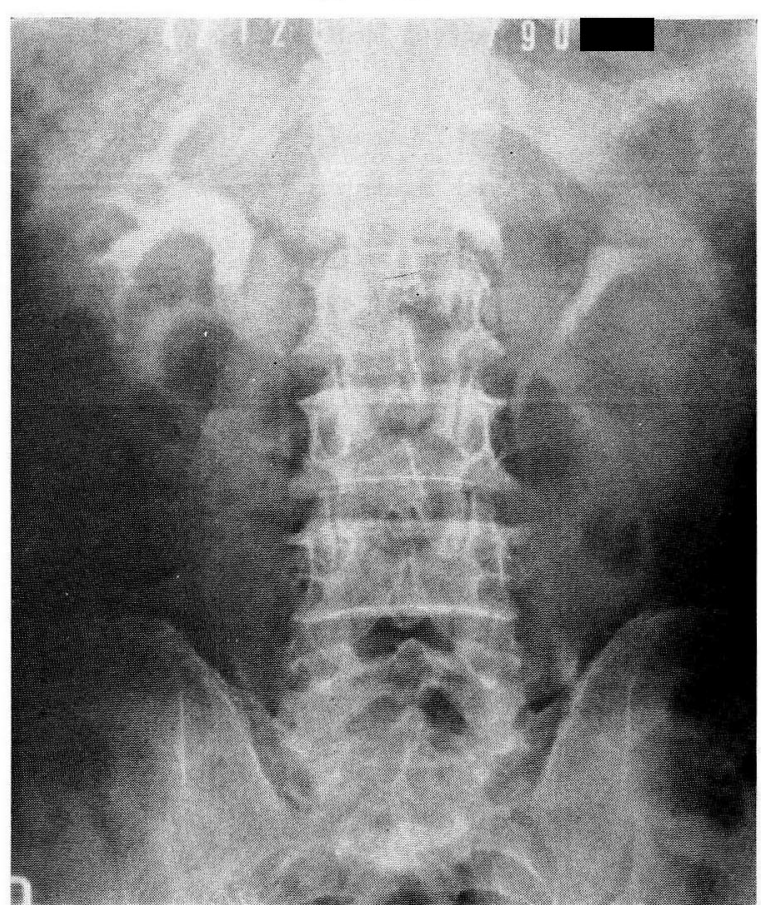

図 20

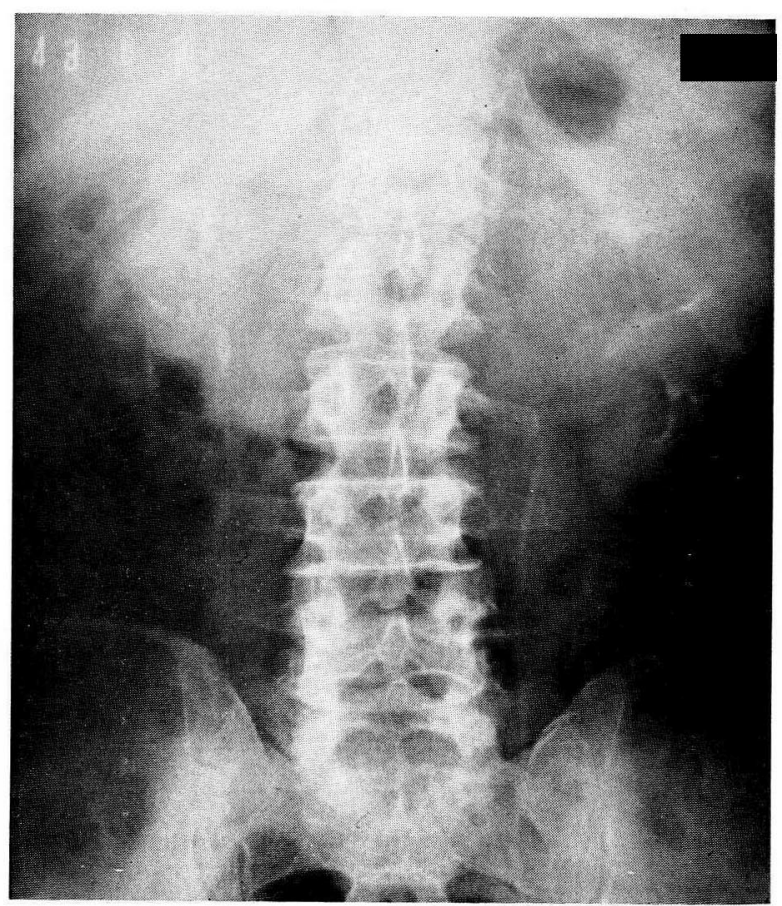



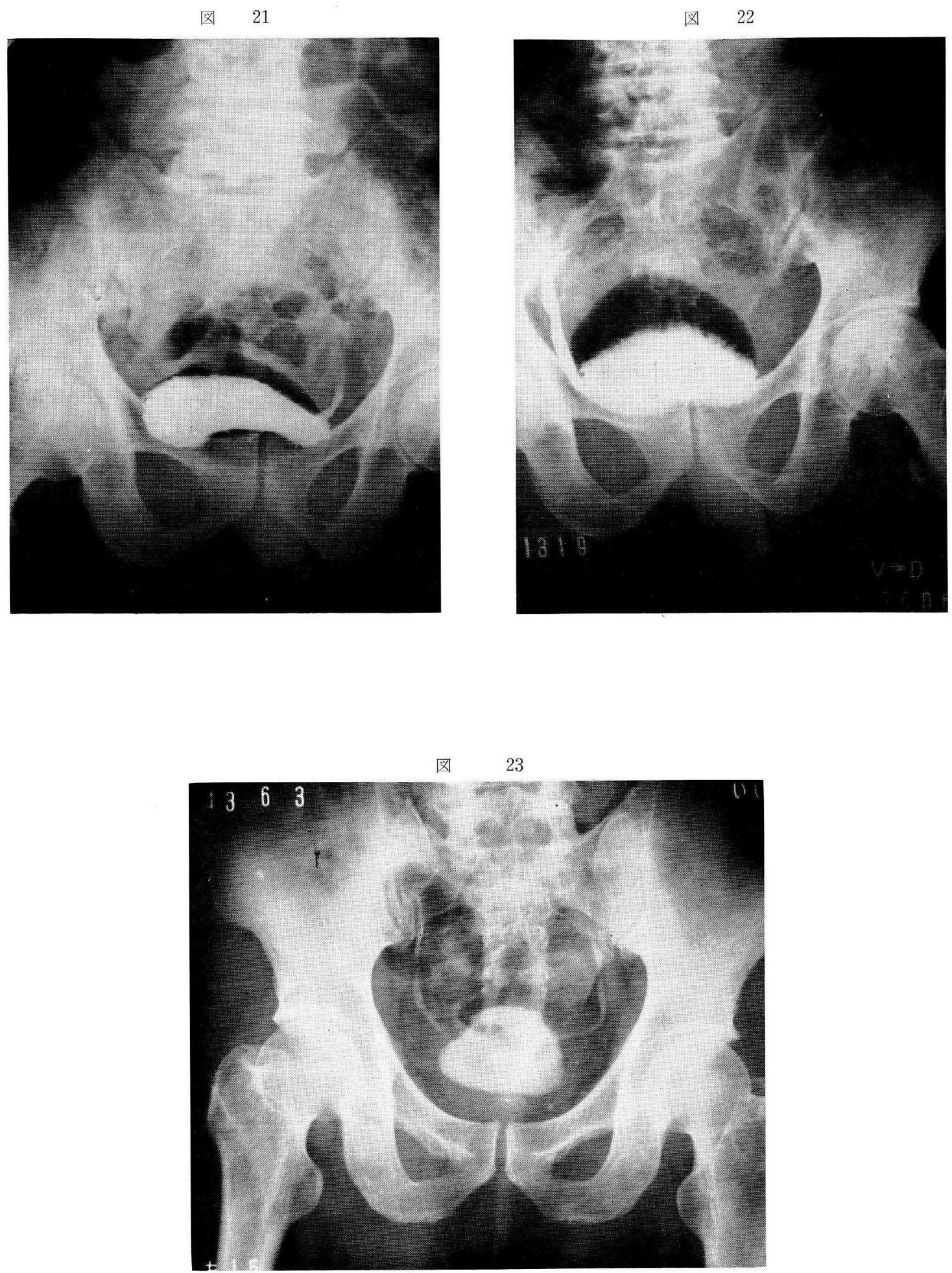
層に移行る。

口）中間層（図 3）：中間層は筋層で，anastomosing strands がみられるが, 内縦, 中輪, 外縦の 3 層が識別 される。

八）外層（図 4）：筋層の外鞘で，線維結合織性の組 織よりなる。この中には多数の血管, 神経を含む原管周 团結合織が連らなつて㧊り，尿管の保護と機能の保持を 果たしている.

尿管外層の周囲には脂肪組織があり，ここには文い血 管が豊富にみられる。

2. 両側上膀脂動脈結禁家鬼

結禁 1 日後のものでは特に変化はみられなかつた。

結紮 5 日後のものでは，上皮細胞の核周囲に空胞形成 がやや増加し，軽度の核の大小不同がみられ，核の染色 性がやや強くなり，一様に染まるようになる（図 5 ）。

結紮10日後のものでは, 核周囲の空胞は, 更に增加し ており, congestion はみられるが, 浮腫はない(図6). 結禁20日後のものでは，筋腐がやや菲薄となり，排列 が乱れる (図 7 ).

結禁25日後のものでは, 粘膜下固有層がやや增加を示 寸 (図 8 ).

結紮40日以後 360 日までのものでは，上皮細胞の空胞 形成はそのまま残こり，固有層の增加はあるが，筋層は 正常の厚さと排列をとりもどしたものと（図 9，10）,筋 層が菲薄化してしまつたものとがみられた（図11，12）。

\section{III 臨 床例}

\section{A. 症例}

再発性膀朕腫瘍28例, 前立腺剔除術の再手術 3 例, 計 31例に両側内腸骨動脈結紮術を行つた。再発性膀胱腫㾨 例は，内腸骨動脈結紮後，腫瘍を剔除した。前立腺剔 術後の再手術例は，1例はTURにより，他の2例は open surgeryにより他医療機関で手術が行われていたも のであるが，前立腺々腫の残存により，再び強度の排尿 困難, 尿閉, 腎機能不全のあつたもので, 既往の手術に より残存腺腫剔出後の止血飞必要な膀胱壁の一部が欠損 あるいは瘢痕化していたため，無用の出血をさけるた め, 内腸骨動脈結紮後, 残存腺腫の処理を行つたもので ある.

\section{B 検查方法}

経静脈性腎孟撮影法, 膀胱レ線撮影法, インヂゴカル ミン排泄試験により，腎，尿管，特に下部尿管を検索し た.

1. 経静脈性腎盂撮影法
手術後 2 週，1力月，2 力月にそれぞれ撮影し，それ 以後は，原則として6カ月毎に 1 回づつ撮影した。

口，膀胱レ線撮影法

高橋大越法拉よび経静脈性腎孟性腎孟撮影時の膀胖撮 影によつた。高橋大越法は, 手術前と手術後 3 週目に行 つた。

八インヂゴカルミン排泄試験

手術前之手術後 1 カ月目に行つた。

C 結果

1. 経静脈性腎盂撮影

31例施行したところ

a）術前，術後ともに腎需，尿管像の全く正常であつ たもの15例（図13）.

b) 術前, 両腎孟飞軽度の水腫があり（図14）, 術後は 全く正常となつたもの 4 例（図15）.

c) 術前, 術後ともに腎盂, 上部尿管に強い水腫が認 められ，不変であつたもの7例（図16）。

d）術前, 軽度の腎水腫があり（図17）, 術後やや增悪 したもの 2 例（図18）.

e）術前腎孟像が不明膫であつたものが (図19), 術後 明膫となつたもの 3 例（図20）。

口. 膀胱レ線撮影

術前の膀胱撮影により 1 側の膀胱尿管逆流の認められ ていたものが (図21), 術後は, 反対側のみに膀脱尿管逆 流の認められたものが 1 例ある（図22）。これは尿管口附 近にみられた腫瘍の剔除が原因と考えられる.

前立腺手術の 3 例は, 術前 3 例とも 1 側乃至両側の膀 脱家管逆流が認められていたが, 術後も不変であつた。

経静脈性腎孟撮影時の膀胼撮影で, 術後下部尿管の水 腫様変化や尿漏を認めたものは，1例子ない（図23）。

八、インヂゴカルミン排泄試験

a) 術前, 術後ともに5'以内に排泄をみたもの18例.

b）術前, 雨側または 1 側に排泄遅延があり, 術後 5 ' 以内に排泄をみたもの 3 例。

c）術前，術後已もに排泄遮延があり，不変であつた もの 6 例.

d）術前排泄遅延があり，術後改善されたが，5'以 上かかつたものが 4 例.

個々の症例についてみると, 経静脈性腎孟像の消長と インヂゴカルミン排泄時間は, ほら゙平行関係にあつた。

\section{IV 総括ならびに考按}

尿管の血管分布については，この部に関係のある臨床 科, 特に泌尿器科, 婦人科領域で古くから注目されて括 
り, 特に化学療法の普及, 麻酔学の進歩と相まつて手術 療法の範囲の拡大とともに, 最近では特に重視されてい る. 婦人科領域では, 主として子宮癌の根治手術の際 尿管への影響, 尿管膣㾇, および上部尿路機能障害の問 題としてとりあげられている ${ }^{3)}$. 泌尿器科領域では, 以 前より尿管結石の手術, あるいは尿路変更術の際の尿管 腸吻合術“などの問題としてもとりあげられている.

尿管の血管分布についての詳細な研究は，比較的少 く，明瞭でなかつた点もあつたが，1904年に Sampson ${ }^{5)}$ が報告してから明らかとなりだした．

Sampson は，従来尿管に沿つて縦走する periureteral arterial plexus と trunksにより全尿管は栄養され， これらの縦走する血管から小さな分技が尿管に出されて いると考えられていたものを改めて, 尿管に沿つて走 行している大動脈, 腎動脈, 卵巣動脈, 腸骨動脈, 子宮 動脈などからの分技が組み合わさつて尿管動脈となつて いるのであつて, arterial plexus は腹膜の上で血管吻合 をなしており，この腹膜技が尿管の栄養を司つていると した。

その後, Harper ${ }^{6)}$, Micaael $^{7)}$, Varverikos ${ }^{8)}$ 等により 尿管の動脈は, 多くの経路のものが入つており, かつ複 雑な変化に富んでいることが知られた.

McCornack \& Anson" ${ }^{9)}$ は, 尿管の血管を3つの部分 に分けて記載し，

1. Superior segment or renal portion, 腎孟から腎 下極の領域をでの尿管で, この部の血管は, 腎動脈（通 常は最も低い位置の hilary artery) から起こつたもの で, 通常短かく, 細い分技で腎孟尿管移行部の前面に直 接入る.ときには supra renal artery から起こり, 上 部尿管に直接入る.

2. Intermediate segment. 腎下極の高さから総腸骨 動脈分岐部のやや上方の部までの尿管に入る血管で, 他 の 2 部分に比してやや貧弱な血管分布である．この部だ けでみると下半分が上半分より，血管はやや豊富であ る. 主として aorta と common iliac arteryから起こつ ている.

3. Inferior segment or pelvic segment. intermediate segmentの下より,尿管が膀胼に移行するまでの部で ある、この部だけでみると, 膀胱近接部が最も血管が多 い。また以上の 3 部分のらち, pelvic segment が最も 血管分布が豊富であり，かつ変化に富んでいるとしてい る.

下部尿管の血管分布についても，多くの研究がある
が，その所見には報告者によつて多少の相違がみられ る. しかし，大別すると総腸骨動脈之内腸骨動脈が供給 源で, 上膀胱動脈, 㑪動脈, 下膀胱動脈, 精管 (子宮) 動脈，上，下慜動脈からの分技があげられている。

しかし Harper ${ }^{6)}$ は，下部尿管への血液供給は，膀胱 動脈と中直晹動脈，腔動脈であるとし，また Rocker \& Braithwaite ${ }^{10)}$ 抢よび Varverikos ${ }^{8}$ は, この部の最も重 要な血液供給は子宮動脈によるものであるとし，ついで 内腸骨動脈の尿管技，上膀胱動脈の尿管技としている. このように下部尿管えの血液供給について意見が分かれ るのは, 骨盤部動脈の variability が本来多いためであ ろら。

しかし下部尿管では血管は豊富であつても，この部の 比較的上の方に総腸骨動脈が僅かに入つているだけで， 他は全て内腸骨動脈より発していることになる.

そのため内腸骨動脈の結紮が，下部尿管の壊死を生ず るとの危険性が考兄られている.

私は，動物実験に家鬼を用いたが，家鬼では上膀胱動 脈は直接総腸骨動脈より分技し，これから出る尿管技が 主として下部尿管を栄養して抒り，この他に内腸骨動脈 系の動脈の分技が細かく下部尿管に分布している.

従つて人の内腸骨動脈の結紮と, 家鬼の上膀脱動脈の 結柇は下部尿管光の影響という点からは同一と考兄られ る.

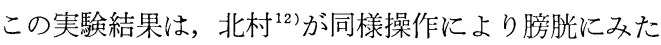
所見のように強い変化はみられず，尿管上皮細胞の軽度 の空胞形成と筋層の軽度の菲薄化を久たのみで, 粘膜固 有層は逆にやや厚くなつて拈り，尿管壁全体としてみる ときは，それ程強い変化とはいえず，ましてや ischaemic necrosis は 1 例もみていない。

また臨床例についてみると，術後腎孟し線像の増悪し たものは31例中 2 例で, 他は元からの正常のままか, 好 転したか，ないしは不変かである。增悪した 2 例も，膀 胱腫瘍の剔除が原因と考兄られ，内腸骨動脈結禁術が原 因とは考兄られないものであり，インヂゴカルミン試験 も腎盂レ線像に比例して好転している。 ましてや尿管漏 の発生したものは 1 例もない。

Orkin $^{9)}$ は, 諸家の報告を検討した後, 下部尿管へ動 脈技を出している子宮, 腔, 膀胱動脈が結紮され, 加兄 て periureteral arterial Sheath とその動脈叢が損傷さ れれば，尿管は疑いもなく脱落する．

また若し内腸骨動脈が遮断されても, periureteral arterial plexusが破壊されなければ，尿管は脱落しない。 
しかし下部尿管の壞死を防止するためには，尿管の血液 供給の障害を最少限度にとડ゙むべきであり，そのため必 要でないならば内腸骨動脈の結禁はすべきでない。もし 内腸骨動脈が結禁され，尿管の周囲に inflammatory exudate, hemorrhage, hematoma などが生じ;このため 副血行路の形成が阻害されれば，尿管は壊死になつてし まうと図示して強調している. Flocks ${ }^{13)}, \mathrm{Nitch}^{14)}$, Coff$e y^{4)}$ らは, 膀胼全剔出術後の尿管腸吻合術の際, 尿管の 栄養状態を探究して, ischaemic necrosis の危険性を強 調し, また Daniel \& Shackman ${ }^{15}$ は, 尿管腸吻合術 では尿管が $2.5 \mathrm{~cm}$ 以上可動性になれば，血液供給の如何 にかかわらず10〜15\%に尿管の ischaemic necrosisを発 生させる恐れがあるという.

この場合に，尿管の切断部が，2 本以上の尿管血管の 吻合部であれば，1本が切られても尿管の栄養は低下し ないが，1 本の尿管血管しかなくて，これが中枢側で切 断されれば，これより末梢側にあるところの尿管では， necrosis の発生をみると，血管吻合を図示している.

このほかにも過度の尿管の移動は, periureteral plexus の損傷を意味するであろう。

われわれの臨床例では, 初期には下膀胱動脈だけを結 紮したが，内腸骨動脈を結紮したのも同様に何ら異变を 生じなかつたので, 以後は全て手術手技の容易である内 腸骨動脈結紫術を行つた。結紮部は総腸骨動脈が内, 外 腸骨動脈に分岐する直下であるが，腎機能の低下，尿管 の変形, 屈曲, 尿漏などはみられておらず, 動物実験例 でも, 組織学的にみて尿管像に強い病変は生じていな い.このことは, 主病変が膀胱上皮に発生する癌である ため, 膀腃を手術的開いて, 単純剔出, 電気切除, あ るいは膀胱部分切除術であつたり, TUR による切除等 を行つたもので，下部尿管周团に直接手術操作を行つて いないため, periureteral arterial plexus を損傷するこ とがなかつたためであろう.

もし，下部尿管の周囲組織に膀胱癌の浸潤が及んでい て，下部尿管の膀胱側を切除し，膀脱へ再吻合するょう にしたときには，内腸骨動脈結禁術が行われていれば, 尿管切断部の壊死の発生が考学られる。

periureteral arterial plexus が健在であるとしても, 副血行部の形成がなされていなければ, 吻論 necrosis と なる。

Daniel \& Shackman ${ }^{15}$ は, at random に100例の尿 管を用いて，50\% micropaque $+15 \%$ gelatine を血管 内に注入して尿管血管の状態を追求しているが，左右の
尿管の血管が必ずしも symmetrical でないという。そ のほか先天性の variation も多いといらが, Harper は, 下部尿管の血管分布のなかに，中直腸動脈をあげてい る. 中直腸動脈は, 上直腸動脈一下腸間莫動脈一腹部 大動脈と連絡のあるところから, 内腸骨動脈が結焚され ても，この経路による下部尿管えの supplementary circulation の形成が考えられる。

\section{$\mathbf{V}$ 結 論}

内腸骨動脈結禁術を行らことによる下部尿管の ischaemic necrosis の発生については，賛否両論がある.

私は，この点を明らかにすべく

1）実験動物を家鬼とし，その血管分布状態からして 上膀胱動脈の結紮を行い, 術後 1 日から 350 日までの尿 管を，組織学的に追求したが，尿管上皮細胞の軽度の空 胞形成と筋層の菲薄化をみたのみで，尿管壁全体として は, 特に異常なく, ischaemic necrosis の発生をみたも のは 1 例もなかつた。

2）臨床症例として28例の再発性膀胼癌と 3 例の前立 腺剔出術の再手術例飞両側内腸骨動脈結皆術を行い, 経 静脈性腎盂撮影, 膀脂レ線撮影, インヂゴカルミン試験 などにより検査したところ，殆んどが術前より症状の好 転をみた。これは同時に行つた膀胱癌の剔出にもよると 考觉られる。

尿漏の発生をみたものは 1 例もなかつた.

以上のことより，両側内腸骨動脈結紮術を行つても下 部尿管周囲の血管網を損傷しなければ， supplementary circulationの形成により ischaemic necrosis の発生はな いと考えられた。

(本論文要旨は, 第57回日本泌尿器科学会総会で発表 した).

終りに臨み本研究に御指導ならびに御校閲頂いた恩師 永田正夫教授，水本竜助助教授に深く感謝いたします。

\section{文献}

1）原田直彥, 福山和宏, 朝倉保, 中谷元太郎, 服 部洋: 泌尿紀要, 10, 196, 1964.

2) 水本竜助, 身吉隆雄, 福地晋, 北村俊一, 增永 昭佳, 片庭義男, 鈴木良徳, 角田和男, 松村茂 夫, 今泉新, 鈴木弘之: 手術, 22, 148, 1968.

3）夏目操: 第19回日本産婦人科学会招請講演, 19 67 年 3 月 31 日.

4) Coffey, R.C.: Brit. J. Urol., 3, 353, 1949.

5) Sampson, J.A.: Bull, Johns Hopkin, Hosp., 15, 39, 1904.

6) Harper, W.E.: Brit. J. Urol., 14, 63, 1942, 
7) Michaels, J.P.: Surg. Gynec. \& Obst., 86, $36,1948$.

8) Varverikos, E.D.: Am. J. Obst. \& Gynec., $63,774,1952$.

9) Orkin, L.A.: Trauma to the Ureter, p. 19 E.A-Davis Comp. Philadelphia, 1964.

10) Rocker, D.C. \& Braithwaite, J.L.: J. Obst. \& Gynaec. Brit. Emp., 58, 609,1951.

11）津崎考道: 実験用動物解剖学, 第 1 巻, 金原出
肘, 東京, 昭和 29 .

12）北村俊一：日泌尿会誌，59，66，1968.

13) Flocks, R.H.: Canad. med. Ass. J., 56, 259, 1947.

14) Nitch, C.A.: 'Proc. R. Soc. Med., 25, 1412. 1932.

15) Daniel, O. \& Shackman, R.: Brit. J. Urol., $24,334,1952$. 